\title{
EVALUATION OF THE RESULTS OF THE HISTORICAL AND LEGAL COMPARISON OF THE JUVENILE JUSTICE OF UKRAINE AND POLAND IN THE 1920s
}

\author{
Denys Shygal and Aisel Omarova \\ d.a.shygal@nlu.edu.ua \\ a.a.omarova@nlu.edu.ua
}

Summary: 1. Introduction. - 2. Interpretation and Evaluation of the Results of Historical and Legal Comparison. 3. Juvenile Justice Authorities of Ukraine and Poland in the 1920s: Experience of Comparison and Evaluation. 4. Evaluation of the Results and Possibility of Forecasting. - 5. Conclusions.

To cite this note: D Shygal, A Omarova 'Evaluation of the Results of the Historical and Legal Comparison of the Juvenile Justice of Ukraine and Poland in the 1920s'2021 2(10) Access to Justice in Eastern Europe 67-85. D0I: 10.33327/AJEE-184.2-a000060

To link to this note: https://doi.org/10.33327/AJEE-18-4.2-a000060

Submitted on 27 Feb 2021 / Revised 29 March 2021 / Approved / 07 Apr 2021 Published online: 01 May 2021

Submit your article to Access to Justice in Eastern Europe http://ajee-journal.com/submissions

\section{ACKNOWLEDGEMENTS}

The authors would like to express their gratitude to the reviewers for their help and to the English editor.

\section{CONFLICT OF INTEREST}

The authors have declared that no conflict of interest or competing interests exist.

\section{CONTRIBUTORS}

Both the co-authors contributed equally to the intellectual discussion underlying this paper, case-law exploration, and writing the draft and are both responsible for the final version of the article. 


\title{
EVALUATION OF THE RESULTS OF THE HISTORICAL AND LEGAL COMPARISON OF THE JUVENILE JUSTICE OF UKRAINE AND POLAND IN THE 1920s
}

\author{
Shygal Denys \\ PhD (Law), Assoc. Prof. of the Department of Legal History, \\ Yaroslav Mudryi National Law University, Kharkiv, Ukraine \\ d.a.shygal@nlu.edu.ua \\ https://orcid.org/0000-0001-5087-4951
}

\section{Omarova Aisel}

PhD (Law), Assist. Prof. of the Department of Legal History, Yaroslav Mudryi National Law University, Kharkiv, Ukraine a.a.omarova@nlu.edu.ua

https://orcid.org/0000-0002-9162-0525

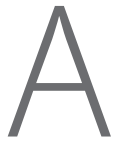

bstract The methodology of comparative historical and legal research is extremely complex, as each stage puts forward a number of specific requirements for the qualification of a historian, as well as for the procedure for working with historical and legal material. However, despite the importance of comparative analysis, which consists of comparing historical and legal objects, the stage of interpreting and evaluating the results of comparative research remains the priority in the context of heuristic knowledge. However, there are still no clear algorithms by which the comparative historian can perform this task, nor is there a general understanding of the direction in which the data obtained during the historicallegal comparison should be explained. Particular difficulties arise in interpreting the results of the comparison of specific historical and legal objects such as the court and the judiciary. In this article, we try to overcome this discrepancy between the theory and practice of the comparative historical and legal method using the comparative analysis of juvenile justice in Ukraine and Poland in the 1920 s, recreating the sequence of actions of a comparative historian, which lead to important scientific results. The structure of the article is determined by its main task and therefore begins with the coverage of theoretical and methodological principles of interpretation and evaluation of the results of comparative historical and legal analysis. In particular, this part deals with the main approaches to the explanation of the data obtained during the comparison of historical and legal objects, as well as the primary rules and principles of their interpretation. The next part of the article is devoted to a specific example comparing juvenile commissions of the Ukrainian SSR and juvenile courts and probation officers of Poland in the 1920s and further explanation of the information obtained. Finally, the last part of the article explores the possibilities and prospects of historical and legal forecasting at the stage of evaluating the results of a comparative study.

Keywords: historical and legal comparison, evaluation of results, interpretation, explanation, forecasting, juvenile justice, juvenile commissions, juvenile courts.

\section{INTRODUCTION}

The development of modern science is closely linked to the improvement of the methodology of cognitive activity. In terms of the scientific and technological progress of the 21 st century, it is critical to provide the researcher with reliable methodological tools, which include both 
individual techniques and methods of scientific research. At the same time, if the content of technical methods and procedures can be discussed only in the specifics of their practical application, then such unanimity of methods in the scientific community has not yet been developed. A large number of scientists refuse to recognise the method solely as a way to achieve a goal, insisting that it also includes both the principles of cognitive activity in the relevant scientific approach and a number of worldviews that permeate the way it is used. Such a different understanding of the scientific method can be explained primarily by its complex structure. Despite all these discussions in the scientific community, most researchers on this issue still agree that the method, in addition to instrumental measurement, also has theoretical fundamentals, which greatly complicates its nature and requires, in turn, a very careful attitude towards the formation of a methodological basis for any scientific research.

Bringing research into line with the new challenges of the modern methodology of historical and legal science acquires special significance in the context of the above. Without history, there is no present, and understanding and planning for the future become impossible. Oddly enough, this thesis does not seem snobbish: the rapid technological development of human civilisation, for all its contradictions, is not able to just as quickly correct the imperfections of human nature, and, therefore, the repetition of events is inevitable. In this sense, it may be salutary to turn to the historical (including historical and legal) experience of mankind, but here, the methodology of historical and legal knowledge may be the weakest link. Clearly, the improvement of the methods of legal history science in such conditions is very important.

Reflecting on possible directions for the modernisation of the methodological potential of legal history science, we think that aligning its theoretical and instrumental levels will be the best solution in modern conditions. It may be manifested, in particular, in the practical implementation of the three-member structure of the method: theory - methodology technique. And since the most relevant scientific tool of historical and legal knowledge is the comparative method, it is necessary to begin this important work with it. This article attempts to analyse the theoretical and methodological foundations of comparative historical and legal research interpretation using the specific example of comparing the juvenile justice of Ukraine and Poland in the 1920s to trace the main components of a comprehensive assessment of the data obtained during comparative analysis. It should also be noted that the interpretation of the results of the historical and legal comparison is the final stage of comparative work, and it is possible only after all the previous stages have been successfully passed, namely: correct selection of the topic of comparative research, collection and study of its source base, conducting a comprehensive comparison of historical and legal objects, systematisation the results, etc. With this scientific work, we continue the series of articles devoted to the development of the theory, methods, and techniques of comparative historical and legal research. The comparative method, which has been the centre of our attention for a long time, has an open architecture, and any scientist can make reasonable changes to it, thus participating in a complex, relevant, and extremely important work to improve historical and legal methodology. This corresponds to the interdisciplinary nature of modern science and is in line with the paradigm of combining nonlinear, dialogical, discursive, and multidirectional approaches to knowledge acquisition. ${ }^{1}$ In other words, the success of scientific communication depends on cooperation between disciplines. ${ }^{2}$

S.E. Vazhynskyi and T.I. Shcherbak rightly noted that the current stage of scientific and technological development of society puts forward some new, much higher requirements for

1 B Belcher, D Suryadarma, A Halimanjaya, 'Evaluating Policy-relevant Research: Lessons from a Series of Theory-based Outcomes Assessments' 2017 (3) Palgrave Communications. DOI: https://doi. org/10.1057/palcomms.2017.17.

2 B Fischhoff, 'Evaluating Science Communication' (2019) 116 (16) PNAS 7670. DOI: www.pnas.org/cgi/ doi/10.1073/pnas.1805863115. 
the creative potential of specialists, which involves mastery of new scientific methods, the ability to navigate the flow of scientific information, and finding the most rational design, technological, and organisational solutions. A modern specialist should have not only indepth training but also a certain amount of knowledge in the field of scientific research, which involves mastering the methodological principles of scientific work and the ability to collect and process information, develop research programs, analyse the results, etc. ${ }^{3}$

\section{INTERPRETATION AND EVALUATION OF THE RESULTS OF HISTORICAL AND LEGAL COMPARISON}

The completion of the systematisation of the results of comparative historical and legal analysis does not mean the end of the comparative historian's work. The results of the comparative study have yet to be interpreted and evaluated. This is because, in a situation of understanding the historical and legal knowledge, the historian of law performs two functions: that of a mediator between the historical past and the present and that of an interpreter of the historical past from the standpoint of the present. The first function follows from his/her status as a researcher: historical and legal material as the basis of historical and legal knowledge is 'dead', unsound. The task of a historian's research activity is not only to identify traces of the past but also to 'voice' them for contemporaries, perform a kind of 'translation' of historical events into an ideal form that will be understood by contemporaries. ${ }^{4}$ The second - interpretive - function of a comparative historian in the process of interpreting the knowledge is determined by the fact that the ideal image of the historical and legal phenomenon by itself says little to the historian's contemporaries. A historian still needs to give some semantic meaning from the standpoint of modernity, to link the results of comparative research with the current problems of modernity, to 'look' at history through the eyes of future generations, and thus give semantic significance to historical and legal events that at present seem insignificant but may significantly affect the future. Moreover, the comparative method itself necessarily has an evaluative character. ${ }^{5}$

The evaluation of scientific research and its results is one of the most difficult problems faced by scientists. ${ }^{6}$ And if we talk about comparative historical and legal analysis, then there are some additional difficulties. For example, V.V. Kosolapov notes that it is the historian who bears a huge social responsibility for the scientific objectivity, content, and comprehensiveness with which he/she presents historical past to his/her contemporaries, at what level he/she conducts a kind of dialogue between the present and the past, and what meaning he/she attaches to it. ${ }^{7}$

The process of explaining or interpreting the results of comparative historical and legal analysis is one of the main objectives of comparative research. Any scientific explanation is

3 SE Vazhynskyi, TI Shcherbak, Methodology and Organization of Scientific Research: Textbook (AS Makarenko Sumy State Pedagogical Institute 2016).

4 From this point of view, the work of J. Kreinath, devoted to the micro-comparative study of religious traditions, is indicative: J Kreinath, 'Implications of Micro-Scale Comparisons for the Study of Entangled Religious Traditions: Reflecting on the Comparative Method in the Study of the Dynamics of Christian-Muslim Relations at a Shared Sacred Site' (2018) 9 Religions 2. DOI: https://doi.org/10.3390/ rel9020045.

5 S Popesku, Aims and Methods of Comparison in Law. Comparative Law (Publishing house 'Progress' 1978).

6 N Salimi, 'Quality Assessment of Scientific Outputs Using the BWM' (2017) 112 Scientometrics 211. DOI: https://doi.org/10.1007/s11192-017-2284-3.

VV Kosolapov, Methodology and Logics of Historical Research (Publishing house 'Vyscha Shkola' 1977). 
a long research process consisting of a number of stages and hierarchically organised levels. For example, T. Luukkonen-Gronow notes that evaluation is carried out at different stages of research work: at the beginning of the project (preliminary), during the study (intermediate), and after the end of the project (final). ${ }^{8}$ Depending on the nature of the explanatory provisions, a number of epistemological types of scientific explanation can be distinguished, which can be used at the stage of systematisation and evaluation of data obtained during the comparison of historical and legal objects. In particular, these are: explanation through the analogy/model; explanation through law, or a set of laws of science; causal explanation; functional and genetic explanation; structural explanation, etc. ${ }^{9}$ The purpose of the whole process of explaining the results of historical and legal comparison, including all its successive stages, reveals the essence of the compared objects and new historical and legal facts and identifies qualitatively new connections between historical and legal phenomena. It should be borne in mind that some types of scientific explanation, listed above, are only stages on the way to discovering the essence of objects, revealing, without touching the whole, their individual aspects and features. For example, the model explanation is simpler, less profound (compared to causal, functional, and genetic), and, as a rule, takes place at the stage of comparative analysis. A striking example of a model explanation of the results of historical and legal comparison is the work of E. Battesini, which compares the Civil Codes of Brazil and the Principles of European Tort Law. ${ }^{10}$

Explanations through the law are the most fundamental type of historical explanation. I.D. Kovalchenko remarks that it is the laws of genesis, functioning, and development of sociohistorical reality that most deeply express its essential nature. ${ }^{11}$ In our opinion, despite this famous statement, the question of historical laws or laws in history is still hotly debated. This is because the reconstructiveness and retrospectiveness of historical knowledge, and hence a certain subjectivity of the researcher, already interfere with giving a comprehensive and accurate assessment of historical phenomena and processes, not to mention the formulation of general laws. This is why it will be extremely difficult to use explanations through historical law in comparative historical and legal research. Nevertheless, the application of sociological laws in the interpretation of certain mass phenomena and processes will be quite appropriate.

Causal explanations of the results of comparative historical and legal analysis can be used more widely than explanations through the law. Based on the commonality of relationships that are objectively present in the historical and legal reality, they are primarily used in the disclosure of certain results of human activity, historical and legal events, and situations in which the active role of the subjective factor is clearly expressed. It is clear that there are certain objective circumstances behind this factor, but they are manifested in the nature of subjective actions.

The genetic explanation is used when the task is to reveal the essence of historical and legal phenomena and processes in their specific temporal expression.

The structural explanation is used to reveal the essence of the compared objects through the analysis of their structure. The main task of the explanation here is to identify the main, systemforming features inherent in the elements of historical and legal objects as systems, as well as to establish the nature of their relationship. The identification of system-forming features is associated with the analysis of the substantive, substantial nature of the compared objects.

$8 \quad$ T Luukkonen-Gronow, 'Scientific Research Evaluation: A Review of Methods and Various Contexts of Their Application' (2007) 17 R\&D Management 207. DOI: 10.1111/j.1467-9310.1987.tb00055.x.

9 EP Nikitin, 'Structure of Scientific Explanation (Formal and Historical Review)' in VS Molodcov, AYa Ilyin (eds), Methodological Problems of Modern Science (MGU Publishing House 1964).

10 E Battesini, 'Comparison of Tort Law Systems from the Perspective of Economic Efficiency: Brazilian Civil Code, Principles of European Law and Restatements of the Law' (2017) 7 (2) Economic Analysis of Law Review 347-361.

11 ID Kovalchenko, Methods of Historical Research (Nauka 2003). 
The functional explanation is aimed at considering the compared objects as subsystems or even elements of higher-level historical and legal systems. Analysis of the structure of the latter allows us to identify the relationship of the compared objects with the environment in which they exist and thus reveal the patterns of their functioning. The functional explanation is an effective way to identify the essence of the compared historical and legal objects at different levels of their functioning.

In addition to the above-mentioned types of explanation of the results of comparative historical and legal research, motivational, psychological, emotional, etc. types have also recently become widespread. The presence of such a number of approaches to the evaluation of the results obtained in the course of historical and legal comparison allows us to develop a structure of evaluation indicators in the future ${ }^{12}$ and, perhaps, even to mathematise the process of data interpretation. From this perspective, the work of a team of authors devoted to the historical comparison of gender inequality in scientific careers in different countries and disciplines, in which the conclusions are based on a fairly large amount of numerical data, is quite interesting. ${ }^{13}$ Regarding the above, M. Krause notes that to the extent that the comparison is related to the explanation, it is usually associated with a linear-causal explanation. However, there are different approaches to explanation, and comparison is also useful for interpreting both different and similar research results (for different reasons). ${ }^{14}$ We cannot disagree with the statement of F. Esser and R. Vliegenthart that more mature comparative studies are explanatory. ${ }^{15}$

The highest level of explanation of the results of comparative historical and legal research (when it allows for a scale of comparison) is the construction of a scientific theory. The historical theory is the most complete and concentrated expression of knowledge in historical science. It summarises and synthesises the facts obtained by the historian at the empirical level of research. With its help, the functions of explanation and prediction of the phenomena of historical reality are carried out, and natural relations within the integral social organisation are opened. ${ }^{16}$

The problem of adequate interpretation of historical and legal phenomena and processes in different socio-economic and temporal dimensions is, obviously, one of the main problems of comparative historical and legal research. This is due not only to the fact that the process of interpretation is influenced by differences in the compared objects, often belonging to different socio-economic systems but also to the fact that researchers of the historical and legal past are often influenced by their own ideological and political beliefs, which in most cases makes it impossible to obtain truly objective knowledge. N. Dagnall, A. Denovan, K.G. Drinkwater, and A. Parker suggest that inflexible adherence to beliefs can affect the evaluation of evidence, regardless of thinking style. Unleashed cognition, in contrast, is impartial and involves the selection and processing of information in a way that is not affected by previous thoughts and expectations. Science, in the strictest sense, is neutral and

12 F Zong, L Wang, 'Evaluation of University Scientific Research Ability Based on the Output of Scitech Papers: A D-AHP Approach’ (2017) 12 (2) PLoS ONE. DOI: https://doi.org/10.1371/journal. pone.0171437.

13 J Huang, AJ Gates, R Sinatra, et al, 'Historical Comparison of Gender Inequality in Scientific Careers Across Countries and Disciplines' (2020) 117 (9) Proceedings of the National Academy of Sciences 4609-4616. DOI: 10.1073/pnas.1914221117.

14 M Krause, 'Comparative Research: Beyond Linear-casual Explanation' in J Deville, M Guggenheim, Z Hrdličková (eds) Practising Comparison: Logics, Relations, Collaborations (Mattering Press 2016). <http://eprints.lse.ac.uk/id/eprint/68362> accessed 29 March 2021.

15 F Esser, R Vliegenthart, 'Comparative Research Methods' in J Matthes, CS Davis, RF Potter (eds), The International Encyclopedia of Communication Research Methods (2017) 12. DOI: ttps://doi. org/10.1002/9781118901731.iecrm0035. 
immoral. ${ }^{17}$ This thesis, in particular, is proved by the work of D. Cabrelli and I.-M. Esser, in which, based on the numerous data obtained during the comparative analysis, they are forced to state that the expected convergence in the field of corporate law has not taken place, and there is no reliable evidence of convergence of national laws in this area. ${ }^{18}$

In the course of mastering the source base of comparative historical and legal research and the reconstruction and comparison of historical and legal objects for the comparativist historian, known and new historical facts are clarified. It often happens that at the end of the actual comparative analysis, the scientist has to deal with a fairly large number of these facts. This is because the category of 'historical fact' is the foundation of the whole building of historical science. The main feature of the study of historical facts, including historical and legal ones, is that they are usually not the subject of direct observation of the researcher and are known through various sources. Historical (historical and legal) facts, along with the conclusions about the similarity or the difference of historical and legal objects, are also the results of comparative research and need to be systematised and evaluated.

The concept of 'fact' (from the Latin factum - 'action', 'event', 'done') is used in different senses. But first of all, a fact is the concrete manifestation of reality in its past or current state, that is, the objective reality. Both historical and legal facts determine the substantial nature of legal history science. There are simpler and more complex facts. In the system of historical and legal knowledge, a historical fact is a 'quantum', i.e., the smallest indivisible part of sociohistorical information about the past, a kind of knowledge that retrospectively reflects any historical changes or states of historical situations and historical events that have become the subject of practical cognitive activities of society. ${ }^{19}$

Historical science has undergone a rather complex evolution in its relation to fact. Initially, it was a priori assumed that the researcher's task is to gather facts. The question of their nature was not even asked. Later, a contradiction between the fact and its interpretation gradually emerged. Some historians still reject the need to generalise and explain this reality because the fact allegedly loses its objective meaning if it is interpreted in any way. In this regard, it is worth noting the opinion of V.V. Kosolapov that the historical fact in itself, beyond its interpretation, is neither true nor false. As an element of historical knowledge and information that corresponds to a historical event, the fact is the basis on which the theoretical generalisations of historical science are based. The purpose of historical theories is to reveal the objective truth through the set of facts and the meaning of historical events that took place. And the broader and richer this factual basis of theories is, the closer the theory is to the objective truth, and the more comprehensive is the reflection of historical reality in them. ${ }^{20}$ In this aspect, the unity and integrity of the qualitative methodology (as opposed to the quantitative) at all stages of comparative research - from the original premises to the analysis and interpretation of data - attracts attention. ${ }^{21}$

It is necessary to agree with the view that there is a tendency to artificially complicate the problem of historical fact. Considerations about its nature and classification are mostly speculative. In this context, it is appropriate to mention the point of view of E.H. Carr. He believes that a historical fact is not just any event, but only the one that is historically significant.

17 N Dagnall, A Denovan, KG Drinkwater et al, 'An Evaluation of the Belief in Science Scale' (2019) 10 Frontiers in Psychology 7. DOI: 10.3389/fpsyg.2019.00861.

18 D Cabrelli, IM Esser, 'A Rule-based Comparison and Analysis of Ten Case Studies. Research Paper Series' in M Siems, D Cabrelli (eds), Comparative Company Law - A Case-Based Approach, 2nd edition (Oxford Hart 2018) 473.

19 Kosolapov (n 7) 292.

20 Kosolapov (n 7) 293.

21 OV Chernysheva, 'Use of Qualitative Methodology in the Research of Life strategies of a Personality' (2016) 9 (14) Tavricheskij nauchnyj obozrevatel 42. 
The scientist should obtain the maximum number of facts relating to the period under study in order to select from them the most significant information and turn it into historical facts and discard insignificant information as non-historical. History is an interpretation, and the relationship between the historian and the facts is a relationship of equality. They need each other. Historians without facts would have no ground under their feet: facts without historians are dead and meaningless. In other words, history is 'a continuous process of interaction between the historian and the facts, an unending dialogue between the present and the past.'22

The work of a comparative historian is a synthesis of empirical and theoretical approaches to the subject of study. The process of selection of factual material presupposes the presence not only of a purely professional qualification but also of a theoretical concept or hypothesis, which significantly influences the selection process. By selecting certain facts from a huge array of information, the comparative historian is already really beginning to carry out their theoretical understanding and explanation. In the course of analysis of historical and legal material and the comparison of historical and legal objects, he/she rises to a higher level of understanding of the subject of his/her work. Rising above the empirical level of comparative research, the scientist increasingly turns to the logical foundations of theoretical understanding and later reveals the true essence of historical and legal phenomena and processes. Finally, the comparative historian should not choose a passive position towards the facts he/she discovered and verified. It is also his/her direct responsibility to establish a hierarchy of facts based on the criteria of scientific significance and cognitive value in the context of a comparative historical and legal study. In particular, this is achieved by comparing historical facts and analysing their interdependence and interactions. In addition, each historical and legal phenomenon ought to be considered not only in its static form but also in its development. Any historical and legal fact established by a comparative historian should also be explained. The explanation itself gives it meaning to a scientific fact. ${ }^{23}$ It should be borne in mind that the semantic load of the fact is different in both the amount of information and its value. This has a certain effect on the scientific nature of the facts themselves. But the reflection of the content of historical facts can only be done by description. That is why the description of the established facts is an important component of comparative historical and legal research. Thus, in the process of describing the facts, all the information obtained during the comparison of historical and legal objects is generalised, the links between the facts and the results of the comparison are established, and certain empirical regularities are revealed.

The translation of empirical data obtained during the comparison into the language of historical and legal science is the most important part of the stage of systematisation and evaluation of the results of comparative research, which is carried out in the form of a scientific explanation. In this case, the better-prepared the material for explanation, the more scientific it is. However, the preparation of historical and legal material for explanation is not always easy. As noted by R. Van Gestel, K. Byland, and A. Lienhard, any legal science is a predominantly nationally oriented discipline, closely intertwined with legal practice and without a clear scientific methodology, ${ }^{24}$ which in itself poses significant difficulties for the comparative historian. The process of explanation is not something separate from the description - description and explanation are in dialectical unity, complementing each other. The description contains elements of explanation, and the explanation is based on the description. As the research process unfolds, penetrating deeper into historical and legal phenomena, the explanation can perform the functions of description, as it becomes

22 E Zhukov, Review of History Methodology (Nauka 1987).

23 GA Berezhnaja, 'Criteria of Scientific Nature of a Fact' in IA Moroz (ed), Methodology of Scientific Perception and Development of Modern Science (DGU 1984).

24 R Van Gestel, K Byland, A Lienhard, 'Evaluation of Legal Research: Comparison of the Outcomes of a Swiss and Dutch National Survey’ (2018) 23 (1) Tilburg Law Review 3. DOI: https://doi.org/10.5334/tilr.6. 
material for a deeper explanation. It should also be borne in mind that the description, as a form of intermediate explanation, is mostly characteristic of qualitative comparative studies; quantitative comparisons often involve the availability of a statistical report. ${ }^{25}$ However, the final assessment of the results of comparative work in both cases is almost always associated with a fairly broad interpretation of the data obtained.

To explain a historical and legal phenomenon is to reveal its essence, that is, to show that this phenomenon is subject to some law (or set of laws). But the established historical and legal fact cannot always be explained by law or theory, i.e., with the help of reliable knowledge. Often hypotheses, i.e., knowledge with a high degree of probability, have to be applied. It should also be taken into account, as noted by P.J. Buckley, that the causes of historical and legal phenomena are rarely isolated. As a rule, a phenomenon becomes possible due to the combined influence of their various states, including the interaction of causes in time and space. ${ }^{26}$ Of course, a fact whose explanation is reliable, all else being equal, is more scientific than a fact whose explanation is hypothetical.

It should be noted that in interpreting the historical and legal fact, a comparative historian can add to it such elements that will significantly affect the reliability of the reflection of historical and legal reality. Different interpretations of historical and legal facts and the absorption of a fact by interpretation create ample opportunities for subjectivism. Interestingly, one of the reasons for this is called the impact on the researcher of the so-called social comparison, which can lead to the conscious or unconscious distortion of the results obtained and their evaluation. ${ }^{27}$ L.P. Grigorian notes that if the objectivity of the same facts is recognised, researchers may have different opinions about their interpretation. Different interpretations of facts lead to different, sometimes nonscientific, understanding of the patterns of development of socio-historical reality. Conversely, a strictly scientific, correct interpretation of socio-historical facts allows the researcher to create a truly scientific view of events and phenomena and determines the coincidence of theory with objective reality. ${ }^{28}$ It is necessary to agree with the opinion of O.O. Razborska and Yu.Yu. Yarova that the objectivity of the assessment of the identified features and the reliability of the conclusions is ensured by the scientific competence and comprehensiveness of the historical and legal analysis, as well as the level of qualification of the comparative historian and his/her experience, morals, and business qualities. ${ }^{29}$ In addition, we should not forget that an important component of any methodological tool is a properly selected conceptual and categorical apparatus, which provides complete disclosure of the problem chosen for research at the appropriate scientific level..$^{30}$

The interpretation of the conclusions of comparative historical and legal analysis, as well as established facts, is a complex cognitive process of determining the meaning of historical and legal events, phenomena, and processes in the course of scientific analysis and theoretical understanding. The point of view of J.I. Piovani and N. Krawczyk deserves attention, according to which comparison is a significant analytical and interpretive resource. ${ }^{31}$ In order to use it, it

25 HH Elkatawneh, 'Comparing Qualitative and Quantitative Approaches' (2016) SSRN Electronic Journal. DOI: 10.2139/ssrn.2742779.

26 PJ Buckley, 'Historical Research Approaches to the Analysis of Internationalisation' (2016) 56 Management International Review 888. DOI: https://doi.org/10.1007/s11575-016-0300-0.

27 S Garcia, A Halldorsson, 'Social Comparison' in R Biswas-Diener, E Diener (eds), Noba Textbook Series: Psychology (Champaign, IL: DEF publishers 2021) <http://noba.to/y4urxhvj> accessed 29 March 2021.

28 LP Grigorian, 'Specifics of Social-Historical Fact Interpretation' in AA Yudin (ed), Methodological Problems of Modern Science (Gorskyi State University Publishing 1986).

29 OO Razborska, YY Yarova, 'Estimation of the Results of Research and Conclusions Formulation by an Expert Accountant' (2011) 28 (1) Zbirnyk naukovykh prats ChDTU 66.

30 N Buhlai, 'Methodology of Research of Polish Foreign Policy (1995-2005)' (2018) 2 Naukovyi visnyk MNU imeni VO Sukhomlynskoho. Istorychni nauky, 2, 53.

31 JI Piovani, N Krawczyk, 'Comparative Studies: Historical, Epistemological and Methodological Notes' (2017) 42 (3) Educação \& Realidade 835. DOI: http://dx.doi.org/10.1590/2175-623667609. 
is important to bear in mind that the interpretation of historical facts has its own specifics due to the complexity and multifaceted nature of historical and legal reality. Thus, in the course of comparative analysis, it is necessary to interpret the established historical facts in two aspects: 1) in the identification of facts to real historical and legal events and 2) in including facts in the general concept of comparative historical and legal research. At the same time, the process of interpretation is influenced by a large number of factors, among which the worldview of comparative historians themselves should be singled out. Therefore, in order to obtain a correct interpretation of a historical fact, it is necessary to separate the subjective aspect and the objective meaning of the fact itself. This is achieved through the use of various logical techniques and methods: abstraction, induction and deduction, analysis and synthesis, and others. In addition, when interpreting the quantitative indicators of the compared objects, it is desirable to avoid general characteristics and focus on concretising own conclusions instead. ${ }^{32}$ In other words, when interpreting, one should strive for clarity of formulations. ${ }^{33}$ D. Makanju, A.G. Livingstone, and J. Sweetman also insist on caution and detail in evaluating the results of the study. ${ }^{34}$

Critical evaluation of comparison results is an important part of comparative historical and legal research. As K. Zweigert and $\mathrm{H}$. Kotz point out, a comparativist must immediately critically evaluate their research; otherwise, it will remain a pile of unused building material. ${ }^{35}$ In addition, it is impossible to draw conclusions about the similarities or differences of historical and legal objects without an idea of the similarities and differences in their characteristics, which are formed, in particular, in the evaluation process. In determining which of the essential features are common and which are similar or different, the evaluation of the identified characteristics of the compared objects, which is the basis for the application of the generalisation technique, is necessary. Due to this technique, the historical and legal phenomena that have common (significant, similar) features are grouped, and the groups can be identification models for comparison with other phenomena. ${ }^{36}$

When assessing the results of comparative historical and legal research, it is necessary to remember that the most important element of the creative search of a legal history scientist is attention not only to individual legal texts or their complexes, to individual historical and legal facts, but also to the broad socio-cultural historical context in which the scattered evidence of the historical existence of law are combined and can acquire their meaning. The legal history scientist ought to penetrate into the spiritual world of the creator of the text, come into direct contact with the society which he/she is studying, and receive unfiltered fragments of the real historical and legal reality, which make the legal history a science. Taking these factors into account, the path to truth lies in the historical knowledge of law, as well as getting rid of the factuality and descriptiveness of legal history science. ${ }^{37}$

Thus, the process of interpretation and evaluation of the results of historical and legal comparison is extremely important and, at the same time, quite a difficult stage of comparative research. A comparative historian, in addition to the proper general methodological preparation for this type of scientific work, must have an appropriate worldview and adhere to a number of specific

32 DC Funder, DJ Ozer, 'Evaluating Effect Size in Psychological Research: Sense and Nonsense' (2019) 2 Advances in Methods and Practices in Psychological Science 166. DOI: 10.1177/2515245919847202.

33 P Aspers, U Corte, 'What is Qualitative in Qualitative Research' (2019) 42 Qualitative Sociology 141. DOI: https://doi.org/10.1007/s11133-019-9413-7.

34 D Makanju, AG Livingstone, J Sweetman, 'Testing the Effect of Historical Representations on Collective Identity and Action' (2020) 15 (4) PLoS ONE 22. DOI: https://doi.org/10.1371/journal.pone.0231051.

35 K Cvajgert, H Kjotc, Introduction to Comparative Law in the sphere of Private Law, vol 1 (Mezhdunarodnyie Otnosheniia 2000).

36 LA Luts, 'Theory of Comparative Law Method. Methods and Means of Comparative Law Research' (2006) 31 State and Law. Political and Legal Sciences 494.

37 MA Damirli, 'Specifics of Historical and Legal Cognition and the New Image of Historical and Legal Science’ (2003) 16 Relevant Problems in Politics 422. 
rules and regulations. In particular, it is desirable for them to avoid any bias when working with systematised material within the topic of their research, to adhere to the principle of maximum objectivity, and to assess comparable historical and legal phenomena and processes on the basis of different approaches, which include, in particular, explanation through law, causal, structural, functional and genetic explanation, etc. The general theoretical training of a comparative historian and the quality of which directly affects the comprehensiveness, complexity, balance, and completeness of the interpretation of the results obtained during the comparison of historical and legal objects should also be mentioned. It is also important to understand the essence of historical and historical-legal facts. The facts are one of the first items to become available for processing by a historian, and therefore knowledge of the specifics of working with them is critical. However, the prescriptions and reservations of historical and legal science set for the stage of interpretation and evaluation of the results of comparative research are not rigid - they only outline the corridor of capabilities of a comparative historian and are only the basis for their creative and truly heuristic conclusions, some of which may even become the foundation for building a new theory.

\section{JUVENILE JUSTICE AUTHORITIES OF UKRAINE AND POLAND IN THE 1920S: EXPERIENCE OF COMPARISON AND EVALUATION}

On 10 March 1919, the formation of the Ukrainian SSR was proclaimed. The First World War, the instability of public administration during the national liberation struggle, the typhus and influenza epidemic, and the famine of 1921 all affected the condition of children and their rights. The child population of Ukraine needed help and protection from the state. One of the initial directions of the juvenile policy and juvenile legislation of the first Soviet governments was to combat child homelessness.

In the first years of Soviet rule, Juvenile Commissions were formed. ${ }^{38}$ These Commissions dealt with cases of liability of persons under the age of 18 who were accused of committing crimes, cases of declaring minors homeless, and cases of adolescents who violated the rules of compulsory labour. ${ }^{39}$ From then on, they replaced juvenile courts. In the pre-revolutionary period, even before the First World War, juvenile courts were established in Ukraine in Kyiv, Kharkiv, Odesa, Katerynoslav, and Mykolayiv. This was in line with the global trend of dealing with juvenile cases through separate courts specifically set up for this purpose. Unfortunately, this positive experience was rejected. In the first years of Soviet Ukraine's existence, the commissions for juvenile affairs included representatives from the People's Commissariats of Education, Justice, Social Security, and Health Care. That is, there were no lawyers in such commissions. This is undoubtedly a negative point in the history of juvenile justice in Ukraine. P.I. Lublinskii, noted that juvenile commissions very often treated homelessness with a formal measure of the severity of the offence and resorted to no more than simple suggestions or reprimands where social assistance and education measures were required. Precisely because the commissions were purely pedagogical in nature, there were several problematic issues:

38 P Mykhailenko, Y Kondratiev, History of the Ukrainian Militia in Documents and Materials, Volume 1: 1917-1925 (Heneza 1997).

39 Decree of the Council of People's Commissioners of the USSR 'On the Responsibility of Minors' of 12 June 1920 in Collection of Laws and Decrees of Workers' and Peasants' Government (1920) 15, Art 281; Decree of All-Ukrainian Labour Committee of the USRR 'On the Minor's Liability for Violating the Rules on Labour Discipline' of 5 July 1920. Collection of Laws and Decrees of Workers' and Peasants' Government of Ukraine (1920) 20, Art 386; Resolution of the Council of People's Commissioners of the USSR 'On Means of Fighting Minor's Homelessness' of 11 June 1921 in Collection of Laws and Decrees of Workers' and Peasants' Government of Ukraine (1922) 11, Art 293. 
1. The commissions did not have the right to impose penalties on those guilty of violating the rights and interests of minors. The right and obligation of the commissions to bring to justice those guilty of violating the rights and interests of minors were provided for. However, any official authority had these rights and responsibilities.

2. The commissions were not given the right to decide on the deprivation of parental rights. This was because no code of substantive or procedural law issued in 1922 had a provision on the possibility of deprivation of parental rights.

3. The decisions of the commissions were not of a formal nature, which was inherent in a court decision. The decisions of the commissions were not read to minors or their parents, they were not provided with copies of these decisions, and they could not be appealed. Resolutions could be reviewed only by the commissions themselves at their own discretion, at the request of persons or institutions involved in the case, and at the request of relatives of the minor.

4. The commissions did not have the right to decide on compensation for damages caused to minors. The victim had to address this issue to the people's court in a civil lawsuit, in which the minor acted as a defendant.

5. The decisions of the commissions were not subject to appeal and review by higher authorities. ${ }^{40}$

As rightly noted by N. M. Krestovska, the system of measures applied by juvenile commissions signified a return to some pre-revolutionary rules of juvenile justice. However, the decrees that formed the basis of these commissions were not aimed at restoring autonomous juvenile justice. On the contrary, they retained the jurisdiction of the juvenile commissions, which existed until 1935. Judicial intervention was carried out only in cases of serious juvenile delinquency. These cases were referred to the jurisdiction of general people's courts, where special panels of courts were organised. ${ }^{41}$

As for punishments, arrest was not applied to minors as a method of administrative and disciplinary punishment. ${ }^{42}$ If it was necessary to impose administrative or disciplinary punishment on minors, arrest was replaced by another method of punishment.

During the new economic policy, new codes were adopted, which also enshrined the rights of children. With the transition to legal construction on the basis of the new economic policy, it was necessary to make changes in the legislation on children, in particular, to soften its declarativeness and to bring the possibility of implementation in practice to the forefront. ${ }^{43}$ According to the Criminal Code of $1922,{ }^{44}$ punishments were not applied to minors under 14 years of age or to minors from 14 to 16 years of age in respect of whom it was deemed possible to limit to measures of medical and pedagogical influence. Moreover, the highest measure of criminal repression (execution) could not be applied to persons who had not reached the age of 18 at the time of the crime. With regard to the participation of children in

$40 \quad$ PI Lublinskii, 'Crime Fighting in Juvenile Age (Social and Legal Aspects)' (1923) YuI PCJ 84, $179-181$.

41 NM Krestovska, Juvenile Law in Ukraine: Historical and Legal Research (Feniks 2008).

42 Decree of All-Ukrainian Central Executive Committee 'On the Impossibility to Apply Arrest as Means of Disciplinary and Administrative Punishment to Minors' of 4 January 1922 in Collection of Laws and Decrees of Workers' and Peasants' Government of Ukraine (1922) 1, Art 9.

43 PI Lublinskii, 'Protection of Childhood and Fight against Homelessness during the period of 10 Years' (1927) Pravo i zhizn 8, 31.

44 Decree of All-Ukrainian Central Executive Committee 'On Introduction of the Criminal Code of the Ukrainian SSR of 23 August 1922 in Collection of Laws and Decrees of Workers' and Peasants' Government of Ukraine (1922) 36, Art 553. 
court, the CrPC of the USSR of $1922^{45}$ prohibited the admission of a person under 14 years of age to the courtroom. The Code of Public Education of $1922^{46}$ introduced certain changes in the composition of juvenile commissions. Thus, from then on, the commission consisted of a chairman (an educator) and two members (a doctor and a lawyer). However, who exactly this lawyer was - a professional lawyer or just a person who was aware of the law - remains a question.

Poland gained its independence in 1918, and the country's economic situation in the postwar period was as difficult as in Ukraine. According to P. Swianiewicz, the division of Polish territory between Russia, Prussia (later Germany), and the Austrian Habsburg Empire in the 19th century posed a challenge to the country's unification after Poland's independence proclamation in $1918 .{ }^{47}$ The juvenile justice system, which was separate from the adult criminal justice system, was established in Poland in the 1920-30s. At the time, the debate on the need to remove juveniles from the adult criminal justice system was influenced by the Youth Movement of Courts, which emerged in some European countries in the early 20th century and relied on the North American 'Child-Saver' movement. Polish scholars and practitioners who made efforts to create a juvenile justice system identified juvenile offenders as different from adults who are still developing. ${ }^{48}$

After the restoration of Poland's independence, the unification of both criminal and civil legislation became a matter of extreme necessity. In the process of drafting the criminal code, it was decided that young people who violated the law should not be treated as 'young adults', so they should not receive the same punishments as adult offenders. ${ }^{49}$ In the first years of Poland's independence, acts of the occupying states were in force, and new legal acts were adopted to regulate issues related to juvenile delinquency. Thus, on 7 February 1919, the decree of the Provisional President Józef Pilsudski facilitated the establishment of courts for minors and the establishment of offices of permanent guardians. On 26 July 1919, the Minister of Justice of the Republic of Poland issued a decree on the establishment of juvenile courts. Three such courts were established on the basis of the above provisions and were located in Warsaw, Lodz, and Lublin. ${ }^{50}$ Later, such a court was opened in Lviv. ${ }^{51}$ Their competence included the consideration of all criminal cases of minors under the age of seventeen. The decree of 26 July 1919 also regulated the issue of so-called social guardians, who can be considered the first probation officers in Poland. Social guardians were appointed by a judge. Their tasks included collecting information on juveniles (as directed by the judge), supervising juveniles who had been suspended, and caring for juveniles who remained under parental supervision or in cases where supervision was improper and required additional

$45 \quad$ Resolution of All-Ukrainian Central Executive Committee 'On Introduction of the Criminal Procedural Code of the Ukrainian SSR of 13 September 1922 in Collection of Laws and Decrees of Workers' and Peasants' Government of Ukraine (1922) 41, Art 598.

46 Resolution of All-Ukrainian Central Executive Committee 'On Coming into Force of Laws on Public Education' of 22 November 1922 in Collection of Laws and Decrees of Workers' and Peasants' Government of Ukraine (1922) 49, Art 729.

47 P Swianiewicz, 'Poland: Europeanization of Subnational Governments' in F Hendriks, A Lidström, J Loughlin (eds), The Oxford Handbook of Local and Regional Democracy in Europe (Oxford Press 2010) 480 .

48 B Stando-Kawecka, 'Poland' in SH Decker, N Marteache (eds), International Handbook of Juvenile Justice (Springer 2017) 345.

49 B Stando-Kawecka, 'Continuity in the Welfare Approach: Juvenile Justice in Poland' in J Junger-Tas, SH Decker (eds), International Handbook of Juvenile Justice (Springer 2006).

$50 \quad \succeq$ Wirkus, 'The Role of the Family Court in Poland in the Prevention of Demoralization and Juvenile Delinquency on the example of Prophylactic and Rehabilitation Activity of robation Officers' (2018) 4 (1) Polish Journal of Criminology 72.

51 O Lypytchuk, 'Legal State of Minors in Polish Judiciary in Interwar Period of Poland' (2006) Bulletin of Lviv Institute. Series: Law 58. 
assistance from a guardian. ${ }^{52}$ It was further decided that a comprehensive regulation on juvenile offenders would be developed together with a new Polish codification of criminal law, ${ }^{53}$ which took place later, namely, the Criminal Procedural Code, which was adopted in 1928, and the Criminal Code, which was adopted in 1932.

Thus, interpreting the results obtained above, it should be noted that Ukraine and Poland gained their independence after the First World War, and both republics had the experience of juvenile policy in their territories. In the early years of Soviet Ukraine, the authorities enshrined certain rights of children and tried to combat the most common problem - homelessness. However, as rightly noted by O.I. Anatolieva, at the first stage of the fight against homelessness, neglect, and juvenile delinquency, which began in 1920 and continued in the first half of 1921, achieving real results was prevented by the socio-economic and political crisis in the country. There were not enough funds for the maintenance of children's institutions. The development of patronage was hampered by the poverty of the majority of the population. A significant problem was the high unemployment rate.$^{54}$ Most of the norms in the legislation on children were declarative in nature and could not be complied with in reality. Even official sources of the People's Education Commissariat of the Ukrainian SSR contained information about the failed experience in combating child homelessness. Thus, institutions that provided only shelter and food for children during the famine, which was meant to fight against child homelessness, often contributed to its spread. The children only came to spend the night and eat and then returned to a homeless lifestyle. ${ }^{55}$ In Poland, by contrast, juvenile policy was evolving, and juvenile courts and probation officers were established. However, the situation in Poland also had its shortcomings. Thus, a strict criterion of awareness of wrongdoing or lack thereof forced a juvenile court judge to make a decision based on the presumption of intellectual capacity at the time of the crime, while the child protection system provided that only a diagnosis of a young person's personality, needs, and rehabilitation opportunities directed the judge's decision to the choice of measures to be applied. Thus, it is clear that these regulations have been the subject of constant controversy and criticism. The second point of dissatisfaction was the small choice of measures of education and protection, as well as the unsatisfactory state of the structure of juvenile justice. Specialised juvenile courts operated only in large cities, and juvenile probation workers were mostly volunteers, of whom there were only a few professionals; the network of educational and correctional institutions was insufficient. Thus, the case-law often ranged between forcibly suspending proceedings or, in serious cases, the need to place some older juveniles in prison. ${ }^{56}$ B. Stando-Kawecka critically notes that there were only a few juvenile courts in Poland before the Second World War. It was not until the 1960s that the number of individual juvenile courts began to grow significantly. ${ }^{57}$

\section{EVALUATION OF RESULTS AND POSSIBILITY OF FORECASTING}

Interestingly, some experts in the field of historical and legal comparative studies do not limit the stage of systematisation and evaluation of the results of comparative historical and legal analysis only to the explanation of the research findings but also include forecasting. According to A.O.

$52 \quad$ Wirkus (n 51) 72.

53 A Marek, 'Juvenile Justice in Poland: Its History and Current Development' (1988) 4 Review of Socialist Law 308.

54 OI Anatolieva, 'Legal Regulation of Combating Homelessness, Neglect and Crime in the USSR in the 20s of the XX century' (Master's thesis, National Academy of Internal Affairs, 2003).

55 Circular Note of People's Education Commissariat of the USSR 'On the Main Issues Concerning Fight against Homelessness of Minors' of 19 November 1924 Bulletin of People`s Education Commissariat (1924) 3-4, 131-132.

57 Stando-Kawecka (n 50). 
Tille, historical-comparative analysis is the basis of any forecasting, which is not an expression of assumptions about the future, but a systematic study of prospects for democracy, governance, law, or their individual institutions, processes, and phenomena using modern methodologies, tools, and techniques of modern scientific knowledge. A forecast is a special type of scientific prediction based on the analysis of deep trends in the development of the object, the nature of the whole system of current factors (permanent and temporary, internal and external, etc.), a reasonable assessment of future development and their possible consequences. ${ }^{58}$

V.Ye. Chirkin, along with descriptive, critical, and heuristic elements of comparison of state, institutions also singles out a forecasting element. A descriptive element of comparisons is necessary for an objective understanding of the factual side of the case. Scientific criticism reveals the pros and cons of objects of comparison. The heuristic element is related to the evaluation of an object in specific conditions. The prognostic element of the comparison indicates the possible development and results of events. According to Chirkin, it not only can but also should contain suggestions and recommendations in order to increase the practical effectiveness of comparative research. ${ }^{59}$

Schematically, the forecast can be represented as follows: by establishing via observation that the appearance of phenomenon A entails, as a rule, the appearance of phenomenon $B$, with the secondary appearance of phenomenon $\mathrm{A}$, it is possible with some probability to predict the appearance of phenomenon B. Or, by establishing a trend or change of phenomenon A according to the series B - C - D, we can, again, with some probability, predict that the phenomenon will take the form D. To strengthen the conclusions associated with the prediction of historical and legal phenomena, it is appropriate for a comparative historian to use meta-analysis as a scientific method, which increases the number of indicators-observations by attracting the results of similar studies conducted by different authors at different times in order to form a representative statistical-homogeneous complex, which is a prerequisite for increasing the reliability of research results to confirm or refute the proposed scientific hypothesis. ${ }^{60}$

It is quite clear, notes A.O. Tille, that forecasting is simpler for natural phenomena and much more difficult for social phenomena, including historical and legal ones. In addition, when forecasting, it is necessary to take into account all the social factors that influenced the formation and change of historical and legal objects. ${ }^{61}$ For example, forecasting based on the results of a comparison of juvenile justice bodies of Ukraine and Poland in the 1920s becomes possible only after taking into account all the differences that existed in the countries under consideration and were due to both the existing state regimes and the social essence of the state because they were the reason for the existence of different models of juvenile justice. Thus, in Poland, it was a judicial-centric model of juvenile justice that worked closely with elements of civil society, and in Ukraine, it was an administrative-centric model that was characteristic of the authoritarian Soviet regime. The formation of different models of juvenile justice in Ukraine and Poland was due to the fact that these countries faced different challenges. In addition, Poland did not have the scale of homelessness and resettlement that existed in Ukraine. That is why in Poland, there was a humane response to crimes committed by minors, and in Ukraine, the priority was to eliminate the social danger of mass homelessness of minors.

It should be noted that forecasting at the stage of evaluating the results of comparative historical and legal research can take place, but it should be based on a solid methodological

$58 \quad$ AA Tille, Socialistic Comparative Legal studies (Yuridicheskaia Literatura 1975).

59 VE Chirkin, 'Comparative Constitutional Law: Methods of Research, Branch of Science, Subject of Study’ (1990) 3 Sovetskoe gosudarstvo i parvo 31.

60 VK Savchuk, PK Haki, 'Meta-Analysis as a Way to Increase the Evidentiality of Research Results' (2018) Scientific Bulletin of NUBiP of Ukraine. Series: Economics, Agriculture Management, Business 290, 239. 
foundation - in particular, the method of modelling. In itself, modelling is a powerful tool for social forecasting based on the construction of various models. Characteristically, in the context of forecasting, it will be most appropriate to use simulation-forecasting models that not only reflect the basic properties of the modelling object but also allow to simulate possible states of the object, different from its actual being. The scope of simulation and forecasting models includes the reflection of the possible, permissible, or desirable in the object (objects) under research. Thus, imitation should establish the most optimum, from the point of view of the set tasks, options of development of historical and legal phenomena and processes.

However, despite some optimism of some representatives of historical and legal science regarding its prognostic function, 'predictions are not always confirmed, especially if they relate to complex phenomena and processes of social development. The current level of construction of complex prognostic models gives satisfactory results only for smoothly flowing processes.' ${ }^{\prime 2}$ As N. Krake notes, the actual consequences often differ from those predicted; nonlinear causal relationships play an important role in erroneous predictions. ${ }^{63}$ In addition, theoretical and methodological problems of the application of simulation and prognostic models have not been developed yet, and there are different opinions about the possible use of simulation and prognostic models in historical and legal science. The difficulty of using simulation models is due to the fact that they must take into account possible changes in the object (objects) and replicate them correctly. This significantly complicates the construction of models, requires increasing their sensitivity to possible trends in the development and operation of modelling objects. ${ }^{64}$

\section{CONCLUSIONS}

The evaluation of the results of historical and legal comparison is of paramount importance for all comparative work. First, it provides an opportunity to correlate the data obtained with the objectives set at the beginning of the study and, if necessary, to adjust its further direction. ${ }^{65}$ Secondly, the explanation of the results of the comparative analysis also allows us to assess the quality of the work done by the comparative historian, which may include several aspects. ${ }^{66} \mathrm{At}$ the same time, despite the possibility of using the method of expert assessments at this stage, ${ }^{67}$ its significance will be somewhat limited, given the specifics of comparative historical and legal research. Thirdly, as illustrated by the example of a comparative analysis of juvenile justice in Ukraine and Poland in the 1920s, assessment of the results of comparative work allows us to qualitatively deepen and expand knowledge about the state and legal phenomena that have become the subject of attention of comparative historians.

It is noteworthy that despite the fact that big data promises to revolutionise the field of scientific knowledge by providing new, highly effective ways of planning, conducting,

$62 \quad$ Kovalchenko (n 11) 381.

63 AN Craik, 'Environmental Assessment: A Comparative Legal Analysis. Forthcoming' in J Vinuales, E Lees (eds), Oxford Handbook of Comparative Environmental Law 21. <https://ssrn.com/ abstract $=3013292>$ accessed 29 March 2021.

64 S Leonelli, 'Scientific Research and Big Data' in The Stanford Encyclopedia of Philosophy $(2020)<\mathrm{https}: / /$ plato.stanford.edu/archives/sum2020/entries/science-big-data> accessed 29 March 2021.

65 A Biloshchytskyi, A Kuchansky, Yu Andrashko et al, 'Evaluation Methods of the Results of Scientific Research Activity of Scientists Based on the Analysis of Publication Citations' (2017) 3, 2 (87) EasternEuropean Journal of Enterprise Technologies 5. DOI: 10.15587/1729-4061.2017.103651.

66 P Martensson, U Fors, SB Wallin et al, 'Evaluating Research: A Multidisciplinary Approach to Assessing Research Practice and Quality’ (2016) 45 (3) Research Policy 594. DOI: https://doi.org/10.1016/j. respol.2015.11.009.

67 PA Kalachikhin, 'A Methodology for the Scientometric Expert Evaluation of Research Results' (2017) 51 Automatic Documentation and Mathematical Linguistics 53. 
disseminating, and evaluating research, the role of a comparativist, who provides a comprehensive explanation of comparative historical and legal research, will still remain extremely important and relevant. This is primarily because mathematical and computational tools designed for big data analysis are often opaque in their operation and assumptions, which can lead to results, the scientific content and reliability of which are difficult to assess. Another key challenge may be to find mechanisms for sharing responsibilities in the big data management system to avoid erroneous, unethical, discriminatory, and unreasonable decisions. Finally, none of the elements of scientific research can be fully controlled, streamlined, or even considered through formal tools because the processes of obtaining and processing data are often so chaotic that they cannot be systematically analysed. ${ }^{68}$

The significance of the researcher's direct contact with historical and legal material is clearly traced through the example of a comparative analysis of juvenile justice bodies of Ukraine and Poland in the 1920s. Assessing the results, we can identify both common and distinctive features of juvenile policy in these states. A common feature was the difficult post-war situation in which Ukraine and Poland found themselves. The differences were in the social conditions, the difficulties faced by these two countries, as well as in the ideology of overcoming these difficulties. Thus, in Ukraine, the ideology of the Soviet regime was based on the need to eradicate socially dangerous elements of society, in this case, minors, and in Poland, it was a humane model of responding to juvenile delinquency, based on the formation of juvenile courts and subsidiary bodies.

\section{REFERENCES}

1. Anatolieva Ol,'Legal Regulation of Combating Homelessness, Neglect and Crime in the USSR in the 20s of the XX century' (Master's thesis, National Academy of Internal Affairs, 2003).

2. Aspers P, Corte U, 'What is Qualitative in Qualitative Research' (2019) 42 Qualitative Sociology 141. DOI: https://doi.org/10.1007/s11133-019-9413-7.

3. Battesini E, 'Comparison of Tort Law Systems from the Perspective of Economic Efficiency: Brazilian Civil Code, Principles of European Law and Restatements of the Law' (2017) 7 (2) Economic Analysis of Law Review 347-361.

4. Belcher B, Suryadarma D, Halimanjaya A,'Evaluating Policy-relevant Research: Lessons from a Series of Theory-based Outcomes Assessments' 2017 (3) Palgrave Communications. DOI: https://doi.org/10.1057/palcomms.2017.17.

5. Berezhnaja GA, 'Criteria of Scientific Nature of a Fact' in IA Moroz (ed), Methodology of Scientific Perception and Development of Modern Science (DGU 1984).

6. Biloshchytskyi A, Kuchansky A, Andrashko Yu et al, 'Evaluation Methods of the Results of Scientific Research Activity of Scientists Based on the Analysis of Publication Citations' (2017) 3, 2 (87) Eastern-European Journal of Enterprise Technologies 5. DOI: 10.15587/17294061.2017.103651.

7. Buckley PJ, 'Historical Research Approaches to the Analysis of Internationalisation' (2016) 56 Management International Review 888. DOI: https://doi.org/10.1007/s11575-016-0300-0.

8. Buhlai N, 'Methodology of Research of Polish Foreign Policy (1995-2005)' (2018) 2 Naukovyi visnyk MNU imeni VO Sukhomlynskoho. Istorychni nauky, 2, 53.

9. Cabrelli D, Esser IM, 'A Rule-based Comparison and Analysis of Ten Case Studies. Research Paper Series' in M Siems, D Cabrelli (eds), Comparative Company Law - A Case-Based Approach, 2nd edition (Oxford Hart 2018) 473.

10. Chernysheva OV, 'Use of Qualitative Methodology in the Research of Life strategies of a Personality' (2016) 9 (14) Tavricheskij nauchnyj obozrevatel 42. 
11. Chirkin VE, 'Comparative Constitutional Law: Methods of Research, Branch of Science, Subject of Study' (1990) 3 Sovetskoe gosudarstvo i parvo 31.

12. Craik AN, 'Environmental Assessment: A Comparative Legal Analysis. Forthcoming' in J Vinuales, E Lees (eds), Oxford Handbook of Comparative Environmental Law 21. <https:// ssrn.com/abstract=3013292> accessed 29 March 2021.

13. Cvajgert $\mathrm{K}$, Kjotc $\mathrm{H}$, Introduction to Comparative Law in the sphere of Private Law, vol 1 (Mezhdunarodnyie Otnosheniia 2000).

14. Dagnall N, Denovan A, Drinkwater KG et al, 'An Evaluation of the Belief in Science Scale' (2019) 10 Frontiers in Psychology 7. DOI: 10.3389/fpsyg.2019.00861.

15. Damirli MA,'Specifics of Historical and Legal Cognition and the New Image of Historical and Legal Science' (2003) 16 Relevant Problems in Politics 422.

16. Elkatawneh HH, 'Comparing Qualitative and Quantitative Approaches' (2016) SSRN Electronic Journal. DOI: 10.2139/ssrn.2742779.

17. Esser F, Vliegenthart R, 'Comparative Research Methods' in J Matthes, CS Davis, RF Potter (eds), The International Encyclopedia of Communication Research Methods (2017) 12. DOI: ttps://doi.org/10.1002/9781118901731.iecrm0035.

18. Fischhoff B ,'Evaluating Science Communication' (2019) 116 (16) PNAS 7670. DOI: www. pnas.org/cgi/doi/10.1073/pnas.1805863115.

19. Funder DC, Ozer DJ, 'Evaluating Effect Size in Psychological Research: Sense and Nonsense' (2019) 2 Advances in Methods and Practices in Psychological Science 166. DOI: $10.1177 / 2515245919847202$.

20. Garcia S, Halldorsson A, 'Social Comparison' in R Biswas-Diener, E Diener (eds), Noba Textbook Series: Psychology (Champaign, IL: DEF publishers 2021) <http://noba.to/ y4urxhvj> accessed 29 March 2021.

21. Grigorian LP, 'Specifics of Social-Historical Fact Interpretation' in AA Yudin (ed), Methodological Problems of Modern Science (Gorskyi State University Publishing 1986).

22. Huang J, Gates AJ, Sinatra R, et al, 'Historical Comparison of Gender Inequality in Scientific Careers Across Countries and Disciplines' (2020) 117 (9) Proceedings of the National Academy of Sciences 4609-4616. DOI: 10.1073/pnas.1914221117.

23. Kalachikhin PA, 'A Methodology for the Scientometric Expert Evaluation of Research Results' (2017) 51 Automatic Documentation and Mathematical Linguistics 53.

24. Kosolapov VV, Methodology and Logics of Historical Research (Publishing house 'Vyscha Shkola' 1977).

25. Kovalchenko ID, Methods of Historical Research (Nauka 2003).

26. Krause M, 'Comparative Research: Beyond Linear-casual Explanation' in J Deville, M Guggenheim, Z Hrdličková (eds) Practising Comparison: Logics, Relations, Collaborations (Mattering Press 2016). <http://eprints.Ise.ac.uk/id/eprint/68362> accessed 29 March 2021.

27. Kreinath J, 'Implications of Micro-Scale Comparisons for the Study of Entangled Religious Traditions: Reflecting on the Comparative Method in the Study of the Dynamics of ChristianMuslim Relations at a Shared Sacred Site' (2018) 9 Religions 2. DOI: https://doi.org/10.3390/ rel9020045.

28. Krestovska NM, Juvenile Law in Ukraine: Historical and Legal Research (Feniks 2008).

29. Leonelli S, 'Scientific Research and Big Data' in The Stanford Encyclopedia of Philosophy (2020) <https://plato.stanford.edu/archives/sum2020/entries/science-big-data> accessed 29 March 2021

30. Lublinskii PI,'Crime Fighting in Juvenile Age (Social and Legal Aspects)' (1923) Yul PCJ 84, 179-181.

31. Lublinskii Pl,'Protection of Childhood and Fight against Homelessness during the period of 10 Years' (1927) Pravo i zhizn 8, 31.

32. Luts LA, 'Theory of Comparative Law Method. Methods and Means of Comparative Law Research' (2006) 31 State and Law. Political and Legal Sciences 494. 
33. Luukkonen-Gronow T, 'Scientific Research Evaluation: A Review of Methods and Various Contexts of Their Application' (2007) 17 R\&D Management 207. DOI: 10.1111/j.14679310.1987.tb00055.x.

34. Lypytchuk O, 'Legal State of Minors in Polish Judiciary in interwar period of Poland' (2006) Bulletin of Lviv Institute. Series: Law 58.

35. Makanju D, Livingstone AG, Sweetman J, 'Testing the Effect of Historical Representations on Collective Identity and Action' (2020) 15 (4) PLoS ONE 22. DOI: https://doi.org/10.1371/ journal.pone.0231051.

36. Marek A, 'Juvenile Justice in Poland: Its History and Current Development' (1988) 4 Review of Socialist Law 308.

37. Martensson P, Fors U, Wallin SB et al, 'Evaluating Research: A Multidisciplinary Approach to Assessing Research Practice and Quality' (2016) 45 (3) Research Policy 594. DOI: https://doi. org/10.1016/j.respol.2015.11.009.

38. Mykhailenko P, Kondratiev Y, History of the Ukrainian Militia in Documents and Materials, Volume 1: 1917-1925 (Heneza 1997).

39. Nikitin EP,'Structure of Scientific Explanation (Formal and Historical Review)'in VS Molodcov, AYa llyin (eds), Methodological Problems of Modern Science (MGU Publishing House 1964).

40. Piovani J, KrawczykN, 'Comparative Studies: Historical, Epistemological and Methodological Notes' (2017) 42 (3) Educação \& Realidade 835. DOI: http://dx.doi.org/10.1590/2175623667609.

41. Popesku S, Aims and Methods of Comparison in Law. Comparative Law (Publishing house 'Progress' 1978).

42. Razborska OO, Yarova YY,'Estimation of the Results of Research and Conclusions Formulation by an Expert Accountant' (2011) 28 (1) Zbirnyk naukovykh prats ChDTU 66.

43. Salimi N,'Quality Assessment of Scientific Outputs Using the BWM'(2017) 112 Scientometrics 211. DOI: https://doi.org/10.1007/s11192-017-2284-3.

44. Savchuk VK, Haki PK, 'Meta-Analysis as a Way to Increase the Evidentiality of Research Results' (2018) Scientific Bulletin of NUBiP of Ukraine. Series: Economics, Agriculture Management, Business 290, 239.

45. Stando-Kawecka B, 'Continuity in the Welfare Approach: Juvenile Justice in Poland' in J Junger-Tas, SH Decker (eds), International Handbook of Juvenile Justice (Springer 2006).

46. Stando-Kawecka B, 'Poland' in SH Decker, N Marteache (eds), International Handbook of Juvenile Justice (Springer 2017) 345.

47. Swianiewicz P, 'Poland: Europeanization of Subnational Governments' in F Hendriks, A Lidström, J Loughlin (eds), The Oxford Handbook of Local and Regional Democracy in Europe (Oxford Press 2010) 480.

48. Tille AA, Socialistic Comparative Legal studies (Yuridicheskaia Literatura 1975).

49. Van Gestel R, Byland K, Lienhard A, 'Evaluation of Legal Research: Comparison of the Outcomes of a Swiss and Dutch National Survey' (2018) 23 (1) Tilburg Law Review 3. DOI: https://doi.org/10.5334/tilr.6.

50. Vazhynskyi SE, Shcherbak TI, Methodology and Organization of Scientific Research: Textbook (AS Makarenko Sumy State Pedagogical Institute 2016).

51. Wirkus $\measuredangle$, 'The Role of the Family Court in Poland in the Prevention of Demoralization and Juvenile Delinquency on the Example of Prophylactic and Rehabilitation Activity of Probation Officers' (2018) 4 (1) Polish Journal of Criminology 72.

52. Zhukov E, Review of History Methodology (Nauka 1987).

53. Zong F, Wang L,'Evaluation of University Scientific Research Ability Based on the Output of Sci-tech Papers: A D-AHP Approach' (2017) 12 (2) PLoS ONE. DOI: https://doi.org/10.1371/ journal.pone.0171437. 